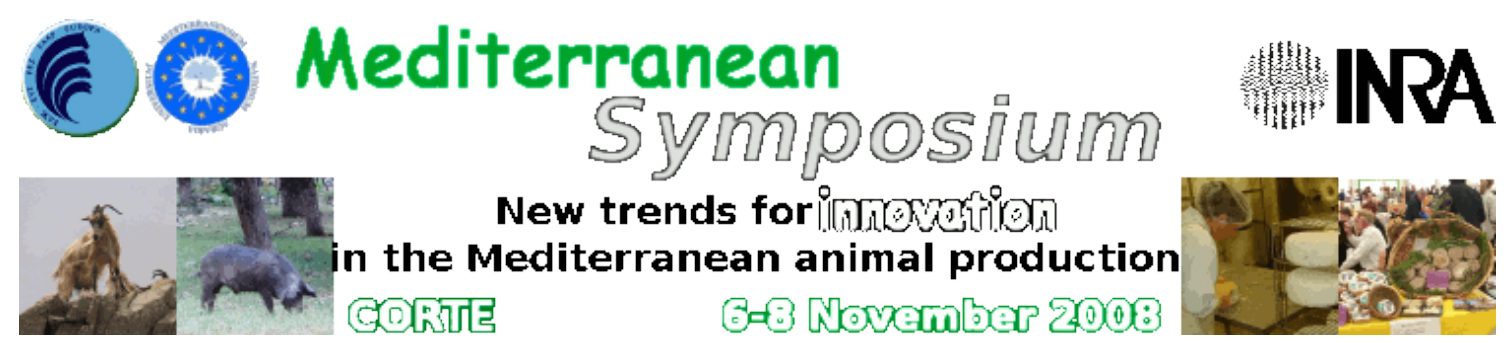

\title{
Innovative strategies of organic beef producers in Italy
}

\author{
F. Ansaloni
}

Dipartimento di Scienze Ambientali, Università di Camerino, Via Fidanza 15, 62024 Matelica (MC), Italy, E-Mail francesco.ansaloni@unicam.it, Internet http://francescoansaloni.unicam.it

\begin{abstract}
In Italy in recent years, organic animal rearing research projects have centred largely on technical aspects while increasing market demand for organic food products has changed business and farmer commercial strategies. The purpose of this study based on the results of a number of Italian national and regional research projects is to analyse income from beef, sales distribution channels and breeder strategies. Our research shows that breeding farms offer a considerable number of products, especially livestock and value added products (fresh meat cuts, salamis) sold directly to consumers in addition to providing tourist and recreational services.

However because organic beef producers have little negotiation power, traditional livestock sales channels are not economically rewarding. The organic beef supply chain stops at the farm stage and therefore organically reared animals are sold at the same price as traditionally reared animals. This situation has motivated some farmers to add meat processing to their normal rearing activities. However not all farmers are to handle successfully the hardships that this short supply chain requires. As an alternative, the farmers could organise themselves into associations to maximise their negotiation power on the market or manage the short supply chain by outsourcing carcass processing to various local abattoirs.
\end{abstract}

Keywords: organic beef, supply chain, value added product

\section{Introduction}

After the adoption of EC Regulation n. 2092 in 1991, the first European law aimed at protecting organic beef production, Italian research projects centred largely on technical aspects. Prior to this EC regulation, organic beef production was simply governed by associations and voluntary certification. In this same period the major changes which influenced production were growing consumer demand for organic food products and variations in technical production costs. Furthermore and in order to improve beef supply chain competitive stance, the behaviour of large commercial food businesses and the 
strategies of individual small organic farms have also undergone changes. Other issues keenly felt in Italy are the need to improve income and market distribution for organic products.

This paper sets out to:

1. illustrate some of the strategies used by farmers;

2. discuss income of organic farms;

3. analyse distribution channels for organic beef.

The themes discussed are of interest not only to farmers but also to public institutions as the latter are mainly concerned with safeguarding organic farms within the territory. This is indirectly true because and thanks to high environmental production sustainability these institutions protect the environment and natural resources to a greater extent. Furthermore increased environmentally sustainable farming methods favour local, traditional and quality products. The thrust to process farm products (value added products) and use direct sales (short distribution chain), are some means to satisfy consumer demand and insure that income remains within the territory where it was generated.

\section{Methodology and results}

The innovative strategies used by organic beef farmers have been presented in a synthesis of the results of three research projects currently underway: the first project EQuIZooBio is an analysis of the income from various organic farm case histories; the second project CANALIBIO examines organic beef distribution channels; the third project ReCUPERO BOVINI FINE CARRIERA illustrates the economic benefits gained by in-farm processing of live animals into fresh meat and other processed products.

\section{Analisi del reddito}

EQuIZooBio an interdisciplinary research project with twenty-two partners is an analysis of the technical aspects of organic farming and cross disciplinary issues such as the environment, animal welfare and economic benefits. The analytical method used to identify and solve problems the creation and study of organic farm case histories in Italy.

Economic analysis was carried out in seventeen of the twenty farms available: five in northern Italy, six in the centre and six in the south. These case histories are extremely varied since the farms are located in different types of terrain (mountain, hill and plane), production lines range from one specific animal to several types (milk for human consumption, milk to be processed, beef). The quantity and the quality of farm resources also vary significantly (land, animals, farm family labour, outsourced labour, type of farm). Lastly multi-activity farms are widespread. The variable nature of these characteristics makes it imperative that farmers are willing to work with the experiments set out in the projects (animal feed, genetics, crop rotation, environmental sustainability and animal welfare). From an economic point of view, these farms do not always represent success stories or real farm models spread over the local territory.

The aim of the economic research is to determine net farm income: total compensation for farmer owned production means actually employed in production. Technical and accounting data were collected during a number visits to the farms where personal interviews were conducted and an identical questionnaire was administered for all types of farms. Income analysis methods were also identical. The data made it possible to calculate net farm income and also income per individual family member (Ansaloni et al., 2006; Ansaloni et al., 
2007). In particular data was obtained to quantify income generating factors in production (agricultural raw material, processed products, services, bonuses and benefits), input necessary to calculate total production costs (land, animals, buildings, machinery, labour, type of farm) and elements to facilitate understanding of the technical aspects of breeding which have a bearing on costs and finally the strong points and objectives of the farm.

As far as production is concerned the farms can be divided into two main types. The first are farms with relatively high labour availability compared to the limited amount of land and/or number of animals. These farms are small family enterprises, medium sized business or socially oriented cooperatives.

In farms with less than twenty hectares of cultivated land per full time work unit our research noted a large number of animal types and consequently the production of a wide variety of agricultural raw materials and in-farm processed goods (cereal, milk and cheese, meat, etc.). Along with other attractions (restaurants, tourism, recreational, cultural, sport, retail). This rather extensive product line is due to the increased labour available with respect to the farm resources, especially land area that has been cultivated.

The second group are farms with limited labour resources for the wide area of land available and the number of animals raised. The majority of these farms are commercial businesses or cooperatives. On farms with more than twenty hectares of cultivated land per full time work unit the product line has been reduced to a limited number of raw materials in order to simplify farm organisation. Furthermore these farms have few and sometimes only one customer.

The reference year used to calculate net income was 2005 but in some cases income was averaged over the two year period 2005-2006. It is interesting to note that income was extremely varied. In fifteen of the seventeen case histories, income was in the black (Ansaloni et al., 2007). The net income per farm is the sum of the compensation for use of farm means available on the farm and for labour by family members involved in farm activity (land, capital, labour, farm risk); income is calculated as the difference between farm intake for the sale of products and services and the total costs sustained in production and calculated at market cost. Income improvement depends mainly on CAP (Common Agricultural Policy) contributions and the sale of processed organic products. Two farms in the study had low incomes with balance sheets in the red. This was due to extraordinary investments to increase herd size and for construction of buildings to start up bed and breakfast businesses. Income depends primarily on animal production and services. In a large part of the cases studied, crop production was primarily used as animal feed for the farmers own animals. The differences in the results is due to the qualitative and quantitative resources available to the farms.

\section{Analysis of organic beef sales distribution channels}

Analysis of the distribution channels for organic beef production strategies was conducted during the two-year period 2004-2005 in the Italian Region of the Marches. In Italy the total number of organic farms was 49,859 of which $89.7 \%$ were agricultural producers. The number of cattle heads raised for milk and for meat was 222,516 (SINAB 2005). The region of the Marches has for a long time been among those areas that has used development policy to favour the growth of organic farms. In 2005 in the Marches, the number of organic farms was 2,651 (Pyszny et al., 2007), while 314 farms reared all types of animals and lastly cattle farms accounted for 117 farms (Assam). According to official Italian statistics "ISTAT 2001", there are 66,283 farms in the Marches; of these 3.99\% over the entire region are dedicated to organic farming. 
Distribution channel data analysis were collected in 2007 directly from cattle rearing farms with at least five hectares of arable farm land. This criterion made it possible to exclude those small non-market oriented farms. Seventy-five out of a total of 109 farms were sampled (Ansaloni et al., 2008a). Data was compiled in direct interviews with the farmers on farm premises using a semi-structured questionnaire as a guideline. This made it possible to define farm resources, income level, processing activities and product distribution channels.

Results show that farmers have limited negotiation powers. Forty-four percent of farmers sell calves to other farms where they will be fattened, 33.3\% of the farms sell baby beef cattle ready for slaughter, $12.0 \%$ sell fresh meat directly to the consumer, $5.3 \%$ sell fattened lamb and lastly 5.3\% sell breeding calves to other farmers.

There are two distribution channels for live beef cattle. In the first channel five month old calves weighing between 200 and 250 kilos are sold to other farms or intermediaries for fattening. The price for these animals is the same as that for animals reared conventionally. The second distribution channel is for baby beef cattle ready for slaughter weighing 500-600 kilos. Again these animals are sold at the same price as conventionally reared animals. In the Marches the organic beef chain stops at the production stage.

Sixty-five percent of the farmers sampled noted difficulties in selling organically reared live cattle. This was primarily due to the unwillingness of consumers to pay higher prices for organic meat and price instability.

The major innovation was the direct sales of fresh meat. In this case the farmer pays a service charge per live head to the local abattoir. After slaughter the farmer collects the carcass and processes it at the in-farm health certified facilities. The farmer sells the fresh meat at his farm shop or personally delivers ten kilo packages of varies cuts directly to customers or some cases sells beef quarters to families. In general and because it is less complicated and sales are constant, the farmer prefers to sell fresh meat to school kitchens, restaurants and local agricultural Bed and Breakfasts. Furthermore and in some cases direct sales means that the farmer-processor can increase the sale price of fresh meat from $10-15 \%$ over the price of the conventional product.

One of the problems noted is that the short beef supply chain is extremely fragile mainly due to two problems. Firstly the farmer has to assume many roles (processor, packager, distributor and sales promoter, etc.) and frequently cover a long distance between the city market and the farm. In $23 \%$ of the cases sampled, farmers encountered difficulties in finding production resources (labour, organic fattening stock and other organic raw materials). The technical efficiency of organic farming was not completely satisfactory and this due to the need for grazing, health factors, animal welfare and neonatal death rate. Lastly in some farms and in contradiction to organic farming methods animals are still kept tied in barns as this latter practice is currently permitted as an exception to the law.

Some areas and especially those producing animal feed, are ideal to create favourable conditions for organic animal rearing. The self sufficiency of the animal feed farm eliminates, or greatly reduces, dependence on third party sources for animal feed. In small mountain or hill country farms there is no substantial difference between organic and conventional farming due to the use of natural fertilizer (manure) rather than market purchased technical means, limited financial resources and modest yields. It becomes clear that organic animal rearing is more economically rewarding when applied over large areas as it reduces production costs. 


\section{In-farm live beef cattle processing: fresh meat and other products}

To increase income some farmers are experimenting with the short supply chain in particular for milk (Coldiretti 2008), fresh meat and corresponding processed products (Prober, 2008; Pyo, 2008). The sale of fresh meat (value added product) allows the farmer engaged in this activity to ask a higher price compared with the normal farm price. Processing demands a complex farm organization needing more labour since processing is added to the existing rearing activities. The short supply chain is therefore not feasible for all farmers.

The short supply chain involves a decision by the farmer to diversify products and attempt to move into a niche market where hopefully sales prices will be significantly higher than ordinary farm market prices. Direct sales by eliminating wholesalers and other intermediaries in effect means abandoning traditional distribution channels. The most common direct sales method is the farm shop, followed by the town market, agricultural Bed and Breakfasts, purchasing groups and the participation in and or supply of processed products to farm fairs and local festivals. Advantages for the farmer are instant encashment and steady cash flow making it possible for the farmer to depend less on bank loans and enjoy greater profit margins.

The third project, an interdisciplinary research project, "Reuse of cattle at working-life end" focused on the cost effectiveness of in-farm live cattle processing of fresh meat and other processed products such as fresh meat from end of working-life milking cows, pigs, lamb, chickens and rabbits, mince, hamburger patties, mixed pork and beef sausage meat, mixed pork and beef salami and bresaola along with other farm shop sales (Ansaloni et al., 2008b).

Because of difficulties encountered in collecting accounting and economic data from the farmers, the research was limited to two farm families which raised Marchigiana beef cattle and other breeds organically. The reference year for this project was 2007 . The average number of animals slaughtered in one year is 27 baby beef, 6 end of working-life cows, 9 light pigs, 19 heavy pigs and 65 lambs. Since 1995, these two farmers have adopted meat processing, innovative sales systems such as "door to door" and "family packs". If the sales price of the processed product is known, it is possible to calculate cost effectiveness of live animal in-farm processing compared to simply selling live animals. The analysis that must be done is to calculate the cost of in-farm processing. (Bernardini, 1960; Cianferoni, 1978; De Benedictis et al., 1979; Giacinti, 1993; Zucchi, 2006).

The first factor that needs to be calculated is the total farm processing costs. This is the difference between processing costs and the net value of the product obtained (e.g., cuts of fresh meat, total number of kilos rendered) multiplied by the sales prices. Processing costs are strictly limited to butchering and do not include herd value for cattle to be slaughtered and processed. Some cost directly related to processing were allowed in the processing cost calculation. This cost is separate from the rearing costs of the farm that produced the animal.

The second factor to be calculated is the processing price per kilo of meat. This is calculated by dividing the total value of processing by the total number of kilos of fresh meat ready for the consumer.

If the processing price is greater than the farm market price of the live animal per head expressed in kilos of fresh meat, processing would be cost effective, otherwise it would not. In our particular case the market price of baby beef weighing 760 kilos live weight expressed as fresh meat was equal to net farm encashment of $€ 2,731.00$ with a yield of 319.20 kilos or $€ 7.43$ per kilo.

The first farm studied was located at 607 metres above sea level in the Marches Apennines. The farm is not near any urban centre and frequented by price sensitive local 
customers who are not particularly interested in buying organic products. The second farm on the other hand, is nearer urban centres and the Marches coast. Customers here are more interested in organic products and willing to pay the higher prices for these. To simplify matters these farms are referred to as rural for the first farm and urban for the second.

Our research shows that prices for conventional or non organic products sold in retail butcher shops in the rural area are equal to or less than those sold by the rural farm. When the rural farm was compared to the urban farm, the research shows that the rural farm had lower prices than the urban farm for all products except bresaola.

Economic results are positive. All processed products with the exception of one product per case history, have been profitable. Covering costs is an interesting item. Both labour costs even when supplied by family members and costs for technical processing equipment are the same as market costs. Often in family-run farms the amount of labour available is excessive with respect to the farmer-processor needs. The farmer-processor in order to avoid not using this labour resource is willing to accept lower than market compensation and ignore fixed costs (management costs, quotas, interest, use of health certified facilities).

The rural farm registers a slight loss for fresh baby beef as it has a lower sales price than the urban farm. Accepting a small underpayment for some factors realigns profits. In addition fixed costs have greater influence in the urban case since the weight of the animals and the amount of the meat sold are lower. Furthermore these farms have few customers interested in purchasing live animals or willing to pay the price of organic products. Some of the strengths of fresh meat are quality, rearing method and long aging period. The weaknesses include short shelf life and the reduced number of customers (school kitchens).

The rural farm did not engage in processing meat from end of working-life animals since its customers did not appreciate this type of meat. The urban farm on the other hand made a profit; its customers were mainly local butchers.

There was no demand for the sale of organic live lambs on the market for either farm. The farm price was the same as the conventional product market price. As far as chickens and rabbits are concerned only the urban farm engaged in this activity. The profit from chickens was positive while that of rabbit was negative. This latter was the only negative result for this farm. Modest quantities of lamb, chicken and rabbit respond to the need to offer clientele cuts of meat other than beef.

In both cases labour hours for farm processing supplied largely by family members was quite high.

The growth of organic farms depends on specific facts other than resources common to conventional farms and CAP contributions. These specific factors are strong demand for food products and the location of the farms in the area.

Product quality as perceived by consumers is one of the main factors that explains strong market demand. Consumers perceive, recognise and prefer organic method certification. Furthermore the consumer recognises the bond with the area (typical products and DOP production regulations) in addition to a trustworthy supplier. The market areas adjacent to urban centres or located close to tourist areas, panoramic sites, historical areas, archaeological sites and natural reserves (natural parks and protected areas) help draw more customers. Consumers equate the territory with quality. They also identify with a number of environmental and ethical values. Direct sales of local food products satisfy demand for low mileage points of sale and help reduce consumers' carbon footprint. In the short food chain or on the stalls in the local farmers' market, agreements with GAS (collective purchasing groups) the sales price is variable and depends on product diversification and provenance. 


\section{Conclusions}

Results show that the organic rearing method and in-farm processing are economically sustainable. In a large part of the case histories in Italy, however, the organic beef supply chain stops at the production stage.

In Italy and in future if supply chains are not developed for the sale of organic meat products with consumers willing to pay a higher price than conventional products and taking into consideration the reduction of direct support through CAP payments, we can only look forward to a return to conventional farming methods by some of those engaged in organic farming.

In-farm processing can improve income and offer opportunities to develop the short supply chain. The complexity of this production method however along with direct sales cannot be applied to all farmers. It is furthermore necessary to have a good understanding of both meat processing techniques and selling techniques. One alternative to individual in-farm processing would be set up inter-provincial associations of farmers capable of insuring a constant supply of live animals. Carcass processing and preparation of processed products could be outsourced to local abattoirs which in turn will be paid for their services. Frequently in fact, the small number of animals reared on the farms is insufficient to cover fixed costs of an in-farm processing plant. Products that need aging like bresaola and salami could be returned to the farm for the aging process. Fresh meat could be stored before sale in freezer warehouses belonging to associations. The problems with this solution is overcoming the individual farmer's diffidence and the need to promote direct sales to urban consumers. Prober (2008) provides an interesting example in the province of Bologna where beef and other food products are sold online and orders from customers are taken from the web site (http://www.mangiocarnebio.it/). Public institutions in order to reward positive effects from organic rearing and support demand for organic meat could help in setting up farmer associations by offering consultations, providing tax advantages and encouraging promotional campaigns to inform consumers about product quality and the complex nature of organic farming.

\section{Acknowledgements}

We would like to thank the farmers who participated in these projects and also the Region of the Marches for its financial support for the three research projects: EQuIZooBio (PI III Fase, Sviluppo Rurale, Zootecnia Biologica, L. 499/99, 2006-2008), CanaliBio (ASSAM, PI III Fase, Sviluppo Rurale, Zootecnia Biologica, L. 499/99, 2006-2007) e ReCuPERo DEI Bovini A FINE CARRIERA (BRS, L.R. 37/99, DGR 1234/05, Regione Marche 2007-2009).

\section{References}

Ansaloni, F., M. Chiorri, A. Menghi, F. Pyszny, G. Schifani \& R. Zanoli 2006 Analisi economica di imprese zootecniche biologiche in italia: primi risultati del progetto di ricerca interdisciplinare E.Qu.I.Zoo.Bio Convegno SIDEA, Assisi, Poster.

Ansaloni, F., M. Chiorri, F. Galioto, G. Guccione, A. Menghi, F. Pyszny \& G. Schifani 2007 Strategie imprenditoriali delle aziende zootecniche biologiche $3^{\circ}$ Workshop GRABIT, Sostenibilità e qualità delle produzioni agricole biologiche, Roma, in corso di stampa.

Ansaloni, F., F. Pyszny \& U. Testa 2008a Market Relationship Organic Beef Cattle 
Breeders in the Region of The Marches (Italy), 16th IFOAM Organic World Congress, Modena, Italy.

Ansaloni, F. \& F. Pyszny 2008b Il reddito delle aziende da carne aumenta con la filiera corta, L'Informatore Agrario 33: 25-28.

Assam 2005 Data Bank, Agency for the services of the agricultural and the food industry sectors of the Marches Region Marche, Ancona, Italy.

Bernardini, C. 1960 Il valore di trasformazione in Esercitazioni di economia agraria, Istituto di Economia e Politica Agraria, Officine Grafiche Calderini, pagg. 190-191, Bologna.

Cianferoni, R. 1978 Guida allo studio dell'Economia e politica agraria, Cedam, Padova.

Coldiretti 2008 Elenco della localizzazione dei distributori automatici di latte fresco, http://www.coldiretti.it/.

De Benedictis, M. \& V. Cosentino 1979 I metodi di pianificazione parziale in Economia dell'azienda agraria, pagg. 601-605, Il Mulino.

Giacinti, R. 1993 L'amministrazione economica dell'azienda agraria, pagg. 155-156, F.Angeli.

Guthrie, J., A. Guthrie, R. Lawson R. \& A. Cameron 2006 Farmers' markets: the small business counter-revolution in food production and retailing British Food Journal Vol. 108 7:560-573.

Hutchinson, K. 2008 Opportunities for Organic Farmers in Local Food 16th FOAM Organic World Congress, Modena.

Istat 2001 Censimento generale dell'agricoltura 2000, Presentazione dei dati definitivi Marche, http://censagr.istat.it/dati.htm.

Morel, B., R. Le Guen, A. Lambert, N. Schieb-Bienfait, G. De Fontguyon \& R. Euzen 2003 Diagnostic et perspective de developpement de la filiere viande bovine biologique des pays de la Loire, Rapport n.2003/08, Programme INRA_DAPD Arpent de la Loire.

Povellato, A. 2006 La zootecnia biologica bovina e suina in Italia: tecniche e mercato, (editor), ESI, INEA.

Prober 2008 Vendita diretta on line di carne fresca e prodotti trasformati http://www.prober.it/mangiocarnebio/

Pyo 2008 Pick Your Own, Raccolta diretta dei consumatori presso le aziende agricole, http://www.pickyourown.org/

Pyszny, F., F. Ansaloni F., F. Cecconi, U. Testa \& P. Bonanni 2007 I bio allevamenti marchigiani continuano a crescere AZBio, 12:49-53.

Sans, P., G. De Fontguyon, B. Sylvander, A. Le Floc'h, M. Auersalmi \& O. Schmid 2004 Is it easy for producers to market organic beef meat? The case of Biobourgogne Viande (France), SAFO, Florence (Italy), 5-7 September 2003, pp. 51-65.

Sinab 2006 L'agricoltura biologica in cifre al 31/12/2005, http://www.sinab.it

Wynen, E. 2006 Organic beef production and marketing in Australia, Journal of Organic Systems, 1.

Veysset, P., S. Ingrand \& M. Limon 2008 Direct marketing of beef in organic suckler cattle farms: economic results and impact on breeding system management, 16th FOAM Organic World Congress, Modena.

Zucchi, G. 2006 Zooeconomia, Economia del sistema delle produzioni animali, pagg.258259, Ed. Avenue Media. 